\title{
The Emergence of the Yugoslav Interwar Liberal Feminist Movement and the Little Entente of Women: An Entangled History Approach (1919-1924)
}

\author{
Isidora Grubački 1*
}

Published: September 8, 2020

\begin{abstract}
This article discusses the interconnected histories of the emergence and growth of the Yugoslav selfproclaimed feminist network in the first half of the 1920s and the regional feminist organisation Little Entente of Women (LEW) founded in 1923. The article suggests the analytical term 'interwar liberal feminism' to point to these feminists' adherence to the liberal constitutional systems of their states and to the post-WWI international state-order, and at the same time to their challenge to the nation-state and their struggle for reforms through parliamentary means regarding women's rights. However, whereas interwar liberal feminists agreed on the problem of the inequality of the sexes in their states and the necessity of related reforms, it is argued that significant ideological differences existed within the interwar liberal feminist movement. By exploring the LEW, the article suggests that this ideological divergence was of a transnational character, which further implies that the LEW should be explored as a dynamic regional organisation whose ambiguous character can be explained by the ideological differences between the involved feminists, rather than through differences between national sections.
\end{abstract}

Keywords: interwar, liberal feminism, Little Entente of Women, Yugoslavia, entangled history

\section{INTRODUCTION}

In recent historiography, the period between the official end of World War I (WWI) in 1918 and 1923 is regarded as a period of profound instability of the social, political, international and gender order (Horne, 2012; Stibbe, 2017). While 1923 can be tentatively marked as a year of piecemeal post-war stabilisation in Europe, it can equally be considered as the year of consolidation of the feminist movements in some South-eastern and Central European (SEE and CE) countries. Namely, this was when Františka Plamínková founded the Czech National Council of Women (Feinberg, 2006: 52-53), when the League for Women's Rights in Greece started publishing its journal O Agonas tis Gynaikas (Woman's struggle) (De Haan et al., 2006: 569-574), and when Alojzija Stebi initiated the founding of the first state-wide self-proclaimed feminist organisation in Yugoslavia, Feministička aliancija u dræ̌avi Srba, Hrvata i Slovenaca (FA, Feminist alliance in the State of Serbs, Croats and Slovenes) (Kecman, 1978: 178-192). It was also in 1923 that feminists from the Kingdom of Serbs, Croats and Slovenes/Yugoslavia (Kingdom SHS), ${ }^{1}$ Czechoslovakia, Romania, Poland, Greece, and Bulgaria established the regional international women's organisation Little Entente of Women (LEW) during the ninth congress of the International Woman Suffrage Alliance (IWSA) in Rome. ${ }^{2}$

Having this larger perspective in mind and building on the growing historiography on SEE and CE feminisms (De Haan et al., 2006; Daskalova and Zimmermann, 2017) this article sets out to enhance our understanding of the character of feminisms in the post-WWI years and interwar feminisms more generally. I suggest the term interwar liberal feminism as a useful analytical tool for discussing the dominant type of feminism in several SEE and CE countries in the interwar period. In order to explicate this term, the article takes as a case study the interconnected emergence and growth of the Yugoslav FA and the LEW in the first half of the 1920s. It is not a

${ }^{1}$ The country's official name was the Kingdom of Serbs, Croats, and Slovenes, and in 1929 it was changed to the Kingdom of Yugoslavia. Yet, Yugoslavia/Yugoslav was used in the 1920s as well, and I will use the two terms interchangeably in this article.

2 IWSA was founded in 1904, and was renamed into International Alliance of Women for Suffrage and Equal Citizenship (IAWSEC) in 1926. 
coincidence that the FA was founded right after the establishment of the LEW in May 1923. Nor is it a coincidence that both these organisations were understood as 'feminist' in the journal Ženski pokret (Women's movement', 1920-1938). ${ }^{3}$ As I will demonstrate, both organisations were created as a result of the new cooperation among women in the context of the post-WWI establishment of new nation-states in SEE and CE.

My analysis relies on transnational and entangled historical approaches, which emerged as a challenge to traditionally practiced historical inquiry that took the nation-state as a dominant unit of analysis (Janz and Schönpflug, 2014; De Haan, 2017). Transnational history is relevant for the case in question as feminist ideas and activities can hardly be understood in isolation from contemporary transnational networks and transfers (Delap, 2009 [2007]: 327). The entangled history approach added several important dimensions to transnational history of border crossings, of which the most important for this article is the interaction among the objects of research, and the ways they 'modify one another reciprocally, as a result of their relationship' (Werner and Zimmermann, 2006: 35). So far, historians of South Eastern and Central European women's movements and feminisms have mostly written from the perspective of the nation-state. Although still relatively limited, the body of scholarship regarding the histories of the LEW (Cheşchebec, 2005: 475-544; Daskalova, 2008; Stefanović, 2013; Milanović, 2017; Daskalova, 2018; Ograjšek Gorenjak and Kardum, 2019) is growing, and so is the literature on SEE and CE women's movements and feminisms in the interwar period from a transnational perspective (Chesschebec, 2005; Daskalova, 2006; Bucur, 2007). The contribution of this article to this emerging body of literature is that it explores the interconnectedness of the national and transnational, i.e. regional levels, in this way shedding new light to the specificities of interwar SEE and CE feminisms, which are still insufficiently theorised. With regards to the LEW, I argue that the ambiguous character of this organisation in the 1920s, as described in the following section, can be explained by ideological divergences shared among LEW women across national sections, rather than by exploring the LEW as an entity made from homogeneous national women's organisations.

The text is primarily based on an analysis of the very few published sources ${ }^{4}$ of the LEW and the Yugoslav journal Ženski pokret, which reported about the LEW congresses and is one of the key sources for exploring Yugoslav women's activism on the local and international levels. The journal was published in Belgrade and contained texts in Serbo-Croatian and Slovenian, in the Cyrillic and Latin alphabet. ${ }^{5}$ Although my analysis largely relies on Yugoslav sources, I maintain that discussing the interconnectedness between the national and transnational levels, and the ways these levels mutually formed each other, can significantly enhance our understanding of both levels, in this case both the Yugoslav women's movement and the LEW. For further contextualisation, I use reports in daily newspapers and reports from IWSA congresses.

\section{INTERWAR LIBERAL FEMINISM: CONCEPTUAL CLARIFICATION}

In a 2017 article on the vocabularies and concepts of global feminisms, Kathryn Gleadle and Zoë Thomas highlighted the importance of research strategies sensible to locally-specific contexts and discourses, which can at the same time remain 'attentive to the global networks and transnational links' (Gleadle \& Thomas, 2017). I find the broad concept of interwar liberal feminism useful for a better understanding of different locally-specific configurations of feminism within the broader, shared framework of the LEW.

As the term explicitly refers to the interwar period, it is important to delineate this context. The 1919-1920 Paris Peace Conference set terms between the victors and defeated countries. The territories of the newly-formed Habsburg 'successor states' of SEE and CE were generally agreed on as well, including the Kingdom SHS (MacMillan, 2002; Adám, 1993: 13-45). Nominally a country uniting Serbs, Croats, and Slovenes, the Kingdom SHS was formed as part of this 'post-war liberal-constitutional order' (Evans, 2007) and as a centralised constitutional and parliamentary monarchy. The new country was unevenly developed and formed out of seven different historical territories, with differing political traditions, legal systems and, because of this different gender law regimes as well. It had slightly over 12 million inhabitants, and its population was over $70 \%$ rural with high illiteracy rates - the rate of illiteracy among women being 61,2\% in 1921 (Crampton, 2007; Janine-Calic, 2019 [2014]; Petranović, 1988; Evans, 2007; Kecman, 1978: 56-60). In 1920-21, the Little Entente (LE) (male) political

\footnotetext{
${ }^{3}$ For important literature on Ženski pokret and more generally Serbian women's periodicals, see the following rich scholarship (Stefanović, 2000; Barać, 2015; Peković, 2015; Dojčinović and Kolarić, 2018; Kolarić, 2019). Recently, Ženski pokret was digitised in Belgrade within the project Ženski pokret 2020, in the context of 100-year anniversary since the first issue. See more about this project at https:/ /www.zenskipokret.org/, as well as Milinković and Svirčev (2019).

${ }^{4}$ Although the members of the LEW had plans to issue a journal of their own, only two conference reports were printed, following the 1923 (1-e Conference, 1923) and 1929 conferences. Ženski pokret published a two-volume report from the 1924 LEW congress in Belgrade, in issues 9 and 10 in 1924 (Atanacković, 1927; Ženski pokret, 1929; Ženski pokret, 1924b). The journal that published on LEW in Prague was Ženská rada (Ograjšek Gorenjak \& Kardum, 2019).

${ }^{5}$ Although published in Belgrade, from 1922 the journal served as a platform of the Yugoslav women's growing feminist network, formalised in 1923 under the name of Feministička aliancija, and in 1926 renamed Alijansa ženskih pokreta.
} 
alliance between Kingdom SHS, Czechoslovakia, and Romania was established, with an antirevisionist agenda to counter mainly the Hungarian, Bulgarian, and German demands for the revision of the Paris Peace Conference decisions. In other words, the LE was a political alliance of the post-WWI winners and new nation-states to protect the territorial status quo in the post-Paris Peace Conference Europe, through which they acquired the contested territories.

With this context in mind, the term liberal refers mainly to the fact that for the interwar liberal feminists in the Kingdom SHS and other countries participating in the LEW, ${ }^{6}$ the nation-states created after WWI were the main framework within which they functioned; neither the state framework, its liberal constitutional system, nor the post-WWI international state-order were to be challenged. At the same time, the nation-state was also their main object of criticism, which they critiqued from a feminist perspective, asking for the reforms to be achieved through parliamentary means, rather than through revolutionary means. ${ }^{7}$ Secondly, the term liberal indicates pluralism within the organisations in question, which gathered women who, although they based their cooperation on the idea of political rights of women and the struggle for a feminist reform of the liberal nation-state, ultimately had profoundly different views regarding the social relations within the nation-state.

In the early years of the Kingdom SHS it is possible to distinguish two dominant streams within the interwar liberal feminist movement. The two groups agreed on the issues of the inequality of the sexes and trust in the liberal state. However, one group had more traditional and hierarchical ideas about society and family. When arguing for women's legal and political rights, they put emphasis on the nation and family and posited an ethnic understanding of the nation. The other group was more left-leaning, as it understood the nation-state primarily in social terms, and connected the women's rights with issues of social justice and equal citizenship of all members of the state, regardless of sex, ethnicity or class. My analysis will suggest that this particular ideological division existed not just in Yugoslavia but more broadly within the interwar liberal feminist movement, at least among the LEW member states.

The article suggests that this ideological division that transgressed the nation-states could be useful for a better understanding of the LEW as well. The organisation was established in 1923, and during the 1920s, its goal was twofold: women's rights and peace. The first goal was 'the complete liberation of women in the countries where women do not have suffrage rights, and a common struggle to achieve all the rights and privileges to all the women before the law and society' (Atanacković, 1923b). Through the LEW, the women established cross-border feminist cooperation, with the ultimate goal to challenge the nation-state that excluded women as equal citizens and attain reforms. The second goal was 'honest and energetic work on the rapprochement of our nations, for the cause of the pacifist idea of the permanent peace' (Atanacković, 1923b). The LEW insisted on the rapprochement of nations and aimed for the creation of conditions for what they imagined as permanent peace. The attainment of peace, in their view, was dependent on the post-Versailles international state system, which was not to be challenged under any circumstances, and thus the LEW could be interpreted as primarily an antirevisionist organisation. This made it less easy to cooperate with feminists from countries defeated in WWI, like Hungary, Germany, and Bulgaria; the fact that Bulgaria ceased being a LEW member already in 1923 is a case in point. ${ }^{8}$

The LEW was an alliance of feminist organisations from the three countries that formed the LE, but it additionally included Poland and Greece. Ograjšek Gorenjak and Kardum (2019: 118) noted that the name LEW turned out to be 'clumsily' chosen due to its too great association with the LE. I would additionally emphasise that mainly because of its strong feminist dimension, the LEW in the 1920s should not be seen as merely a female version of the LE. Rather, the LEW can be described as an ambiguous organisation, whose meaning was permanently negotiated and contested by the participating women. Because the main goal was defined in two points—women's rights and peace-and because the nation-state was the feminists' main framework and main object of criticism, the character of the LEW was ambiguous, i.e. difficult to classify in the 1920s. Although the feminist and national interests were largely compatible (Ograjšek Gorenjak and Kardum, 2019: 120), various LEW members and the general public could interpret them differently, and the possibility of emphasising one of the two aspects produced differing representations of the LEW. Thus, LEW could be perceived and presented as primarily a cross-border organisation of feminists who gathered to challenge their nation-states from a feminist perspective.

\footnotetext{
${ }^{6}$ The countries I have in mind here are: Romania, Czechoslovakia, Poland, and Greece. As will be explained later, Bulgaria ceased being a member shortly after the LEW's founding.

${ }^{7}$ For an account of revolutions and counterrevolutions in Europe 1917-1923, see (Newman, 2017).

${ }^{8}$ While this issue certainly deserves a more elaborate analysis, it is important to say that the Bulgarian representative in Rome, Jeni Bozhilova-Pateva, initially signed the agreement to participate in the LEW (1923 IWSA Report, 1923: 10). From the perspective of the Yugoslav sources, the Bulgarian delegation was excluded because of spreading brochures on the international summer school of Women's International League for Peace and Freedom in the summer of 1923 (Albrechtova, 1924), which was considered a revisionist activity by the Yugoslav delegation. For the Bulgarian perspective see Daskalova (2018).
} 
Or, conversely, as an organisation similar to the LE which women primarily joined to protect the post-WWI status quo.

For reasons outside of this article's focus, the LEW was reorganised on Czech feminist Františka Plamínková's initiative in 1934. The 1930s LEW was more similar to the men's LE, and the member countries were Yugoslavia, Czechoslovakia and Romania. In the words of Ženski pokret's member Milena Atanackovićp, the program had narrowed to 'work on the mutual acquaintance and rapprochement of the nations, and particularly women, of the countries of the LEW, and on the mutual support in all international, and when it's needed also national, endeavours and actions' (Atanacković, 1938). In other words, the national aspect now dominated the feminist aspect.

\section{AN OVERVIEW OF THE YUGOSLAV WOMEN'S NATIONAL AND TRANSNATIONAL ORGANISING IN THE 1920S}

In Kingdom SHS, the women who wanted to develop cooperation on the state level came from different places, mainly from Belgrade, Ljubljana, and Zagreb. Even more importantly, they also came from different political traditions of women's activism. The cases of Delfa Ivanić (1881-1972) and Alojzija Štebi (1883-1956) are good examples. Serbian pre-WWI national liberal feminist Ivanić was one of the founders of the patriotic women's society Kolo srpskih sestara (The circle of Serbian sisters) in 1903, and one of the key figures in the national women's organisation Srpski narodni ženski savez. (SNŽS, Serbian National Women's Council) established in 1906 (Stefanović, 2013: 208-225, 261-278; Milanović, 2015; Stolić, 2015: 152-163). Ivanić was an adherent of the dominant argumentation of the pre-WWI period, that women's education was the key to preserving the family and nation (Kolarić, 2016: 121; Stolić, 2015: 141-142). Slovene Alojzija Štebi was before WWI active in the Jugoslovanska socialdemokratska stranka (JSDS, Yugoslav Social Democratic party), and in 1919 she left the party and subsequently became superintendent of the Department of Youth Welfare in Ljubljana (Selišnik, 2011; De Haan et al., 2006: 530-533). After the WWI, women as different as Ivanić and Štebi would cooperate in what I call the interwar liberal feminist movement in the new country of the Kingdom SHS. However, even though their cooperation was based on the need to reform the post-WWI nation-state from the feminist perspective, they - unsurprisingly - had different conceptualisations of feminism, which I see as divergence within the interwar liberal feminism. ${ }^{10}$

The first wider intellectual cooperation of women in Yugoslavia happened already during the war in the journal Ženski svijet ('Women's world', 1917-1918), and was continued in Jugoslavenska žena ('Yugoslav woman', 1918-1920), published in Zagreb. ${ }^{11}$ Then, in October 1919 a congress was held in Belgrade on which the pre-war national women's council NŽS was re-established, now renamed Narodni ženskei savez Kraljevine Srba, Hrvata i Slovenaca (NŽS SHS, National Women's Alliance of the Kingdom of Serbs, Croats and Slovenes). ${ }^{12}$ NŽS SHS connected over two hundred charitable, humanitarian, patriotic and feminist women's organisations; however, the organisation's primary goal was the unification of all women from the new state. NŽS SHS immediately became member of two most relevant international women's organisations of the first half of the twentieth century: the International Council of Women (ICW, established in 1888) and IWSA/IAWSEC (Rupp, 1997). ${ }^{13}$ The FA was established parallel to NŽS in 1923, and one of its initiators was Alojzija Štebi. According to her, NŽS did not have many organisations that could be characterised as feminist (Štebi, Za novi smer u feminističkom pokretu, 1924d), whereas she considered the FA a 'purely feminist' organisation. This suggests that she had a specific idea about the differentiation between 'feminist' and 'non-feminist' organisations. ${ }^{14}$ The formalisation of the FA had a long-term relevance. It initiated the creation of new organisations with the name of Ženski pokret across the country, and in 1926 it was restructured and renamed into Alijansa ženskih pokereta (AŽP, Alliance of Women's Movements). Štebi served as its president until WWII.

\footnotetext{
${ }^{9}$ Milena Atanacković closely cooperated with Alojzija Štebi, and from 1923 until WWII she was a member of almost all delegations of Yugoslav women on various international congresses.

10 The examples of Ivanić and Štebi should not be understood here as representing Serbian and Slovenian positions, respectively, but the two were chosen mainly for their prominent positions in the Yugoslav interwar liberal feminist movement. 11 On Ženski svijet, in 1918 renamed Jugoslavenska žena see (Ograjšek Gorenjak, 2014; Svirčev, 2015).

12 Delfa Ivanić served as the president of NŽS SHS between 1923 and 1925.

${ }^{13}$ In fact, the new NŽS SHS was a 'successor' of Serbian NŽS, established already in 1906, which had been also a member of ICW and IWSA.

${ }^{14}$ The founding organisations of FA were Slovenian Splošno slovensko žensko drusttvo (General Slovene Women's Association), the Zagreb-based Udrǔ̌enje Jugoslovenskih žena (Association of Yugoslav Women); and the Belgrade Društvo za prosvécivanje žene $i$ zaštitu njenih prava (Society for the Education of Woman and the Protection of Her Rights), soon afterwards renamed Ženski pokret (̌̌P, Women's Movement).
}

$4 / 15$

C 2020 by Author/s 


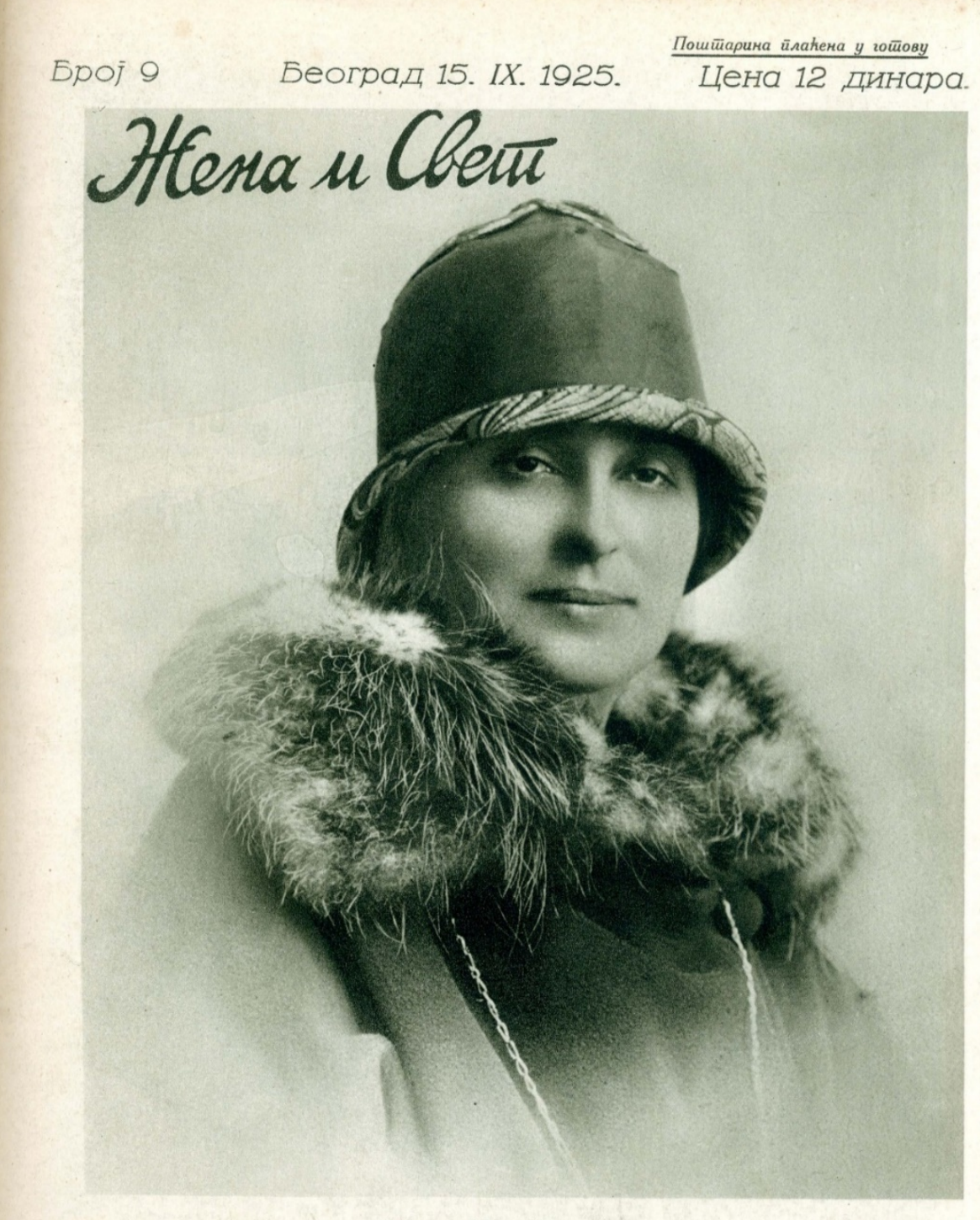

Делфа Нв. Нванића

велика и неуморна ӣоборница на задобијању жсенких ӣрава, оснивачица и I. ӣоӣйредседница Кола Срйских Сесйара, ӥредседница Народног Женског Савеза, добровољна болничарка, која йрва у нашој земљи има највеће одликовање мебународног Црвеног Крсӣа, јак радник на ӣле менском зблиюсаваюу, залаюе се за сваку акцију ге наша экена има да донесе свој глас.

Figure 1. Delfa Ivanić. Žena i svet, 9 (1925). Digitalna Narodna biblioteka Srbije, https://digitalna.nb.rs/wb/NBS/ casopisi_pretrazivi_po_datumu/zena_i_svet/1925/09/b009\#page/0/mode/1up

The establishment of the FA, this article argues, is closely entangled with the establishment of the LEW. The organisation from Kingdom SHS that participated in founding the LEW on the 1923 IWSA congress was the selfproclaimed feminist Ženski pokret from Belgrade. In the cases of other member countries, member organisations were of different scales, namely national women's organisations in the case of Czechoslovakia and Romania, but also smaller women's rights, i.e. feminist organisations from Czechoslovakia, Poland, and Greece. ${ }^{15}$ Following the IWSA congress, the FA was established as a state-wide feminist organisation in order to ensure that the feminists from the whole country, and not only from Belgrade, are represented in the LEW. When LEW was restructured in the 1930s, the member organisations were no longer the women's rights organisations from the countries represented in the LEW, but the national women's organisations from Yugoslavia, Romania, and Czechoslovakia. ${ }^{16}$ The following two sections will discuss FA and LEW, respectively, pointing to the entangled history of these organisations' emergence.

15 The Political Club of Progressive Women from Poland, the Alliance for Women's Suffrage from Czechoslovakia, and League for Women's Rights from Greece (Cheşchebec, 2005: 511).

${ }^{16}$ In 1935, AŽP (FA's successor since 1926) handed the representation of the LEW to the NŽS (at that time Jugoslovenski ženski savez, Yugoslav Women's Council) (Atanacković, 1938). 


\section{THE POST-WWI GROWTH OF THE FEMINIST NETWORK IN YUGOSLAVIA AND THE ESTABLISHMENT OF THE YUGOSLAV FEMINISTIČKA ALIANCIJA (FEMINIST ALLIANCE) IN 1923}

After WWI, women's activism regarding suffrage and women's legal and political rights in the Kingdom SHS radicalised and diversified. As previously mentioned, before WWI the dominant feminist argumentation, as with Ivanić, connected women's rights mainly to the ethnic-nation and family. Whereas this argumentation did not disappear, in the early post-war years different feminist approaches emerged. Namely, Yugoslav feminists sought cooperation with the state's institutions, expressed trust in its constitutionalism and parliamentary democracy, and began to emphasise women's political rights based on the contribution to the state through their public work. The disillusionment with the 1921 Constitution that did not grant women equal political and civic rights however led to an increased and new type of cooperation between Serbian, Slovenian, and Croatian feminists. The situation was similar in, for example, Romania (Bucur, 2001), as well as in many countries in which women bad been granted suffrage rights after WWI. In the Czechoslovak case, for example, even though many women believed that with the right to vote there would be no need for women's organisations, it soon became clear that political parties were insufficiently open to dealing with women's concerns, which is why the Czech feminist Františka Plaminkova founded the Czech National Council of Women (Feinberg, 2006: 53).

Ženski pokret is a case in point for the new type of feminist practice and argumentation in the context of the new state, as it played the key role in the Yugoslav interwar feminist movement. It was founded in April 1919 by a group of highly-educated women ${ }^{17}$ and - in the words of one of its founders - the intellectuals of the older generation', including Ivanić (Lebl Albala, 2005: 244). In its first year, it had around 900 members (Z.K., 1920), and their journal Ženski pokeret had 1200 subscribers. (Bogdanović, 1921). ${ }^{18}$ Ženski pokręs activities are indicative of the scope of liberal feminists in the 1920s - they focused on the awakening of women's social and political consciousness through numerous lectures considered important for the propagation of feminist ideas; they organised numerous literacy courses, domestic schools for peasant women, and sewing courses (Emmert, 1999; Karadžić, 1921). Ženski pokeret distinguished itself by explicitly demanding political rights for women.

In its first year, Ženski pokret immediately proposed cooperation with the state, more specifically with the Ministries for Social Politics, Public Health, and Education. For instance, Ženskipokret asked from the Ministry for Social Politics to include women in the work of solving the housing problem and cooperated with the Ministry of Education in making the illiteracy census (Z.K., 1920; Ženski pokret, 1921a). This kind of work which Ženski pokret did in cooperation with the state led its members to argue for women's political rights in relation to women's public work. They demanded 'complete equality before the law of all members of the society', and argued that political rights were merely means to allow women's direct influence on 'the establishment of a better and more just social system' (Ženski pokret, 1924c). Moreover, they maintained that the feminists' first step was to raise consciousness of the positive sides of women's education and public work, primarily because the state would benefit from it (Karadžić, 1922).

However, the Kingdom SHS Constitution of June 1921 left the question of women's suffrage open (Ograjšek Gorenjak, 2014: 91-112), which led to a growing disillusionment with the ways the new state related to 'the woman question,' and raised women's consciousness of the importance of organising. Serbian, Slovenian, and Croatian women's cooperation, which started in the framework of NŽS, intensified with coordinated campaigns for women's suffrage in early 1921 (Kecman, 1978: 180; Ženski pokret, 1921b). Then, Štebi proposed that all Slovenian societies gather around the journal Ženskipokret (Janković, 1921), and consequently Ženskipokret became the official journal of all feminists in Kingdom SHS from 1922. The cooperation was, therefore, no longer primarily sought with state institutions, but rather among women across the country.

The influence of former Social Democratic Party member Štebi in the Yugoslav network from this moment increased. Štebi was not only the initiator of women's cooperation around the journal Ženski pokeret; she also amplified a discourse that put even more emphasis on the issues of social work and social justice. In her first contributions about prostitution and the protection of children, for example, she identified poverty as the main cause of prostitution and youth delinquency, and insisted that it was everybody's social duty to contribute to society and to the complete transformation of social order leading to the final goal of eliminating social injustice. She argued that women could do this only by attaining political rights first (Štebi, 1922a; 1922b). Even though women's rights were still often discussed in relation to the family and ethnic-nation, the argumentation offered by Štebi

\footnotetext{
${ }^{17}$ The fact that before 1912 only 117 women had studied at Belgrade University gives an insight into how much of a rarity university educated women were (Stolić, 2015: 84).

${ }^{18}$ Out of 1200 subscribers, 371 were from Belgrade, 292 from Bosnia and Herzegovina, around 300 in other Serbian parts of the country, 113 in Croatia and Slavonia, and only 6 in Slovenia.
} 
made increasingly visible an alternative discourse that connected women's rights with the state understood in social, rather than ethnic national terms.

The increased cooperation between Serbian, Slovenian, and Croatian women around the journal Ženski pokret led to the establishment of the state-wide self-proclaimed network Feministicka aliancija (FA). Its declared goal was firmer, stronger, and better actions for the attainment of feminist demands (Atanacković, 1923a). The FA rules did not differ much from Ženski pokret's earlier program. The argumentation was liberal feminist, as the stated goal was to liberate women by the acquisition of political rights and by introducing reforms in terms of the law amendments, and in terms of change of social customs, with the final aim of reaching complete equality between men and women' (Ženski pokret, 1923b: 455). One novelty was that FA's program demanded political emancipation of allwomen, based on the claim that all women's work, including that of mothers and housewives, was productive and contributed to the state's economy.

Whereas disillusionment with and feminist critique of the state led to increased cooperation among feminists from Belgrade, Zagreb, and Ljubljana and then the establishment of the FA, this is only one part of the story of the creation of this organisation. Another part has to do with entanglements between the national and the transnational level. It was only after returning from the ninth congress of the IWSA held in May 1923 that the Yugoslav delegates decided to formally establish the FA, what they called a 'purely feminist Alliance in our country' (Atanacković, 1923a). The reports in Ženskipokret indicate that the inspiration for this initiative came from the fact that during the congress in Rome, the IWSA rejected the ICW's proposition that the two organisations join forces. Reportedly, the argument was that the membership of ICW encompassed many humanitarian and charitable women's societies which had a different sphere of action than IWSA's, whose members are only 'feminist' societies, and 'which considers as its main goal political rights of women, because political rights are the only rational means that would allow women to truly take participation in the society's creation as powerful factors' (Ženski pokret, 1923a). Therefore, at this time, it was insisted on a clear differentiation between 'feminist' and non-feminist, i.e. charitable and humanitarian women's organisations. The following section will explore the LEW and seek for the parallels with FA in terms of its feminist aspects.

\section{THE AMBIGUOUS CHARACTER OF THE LITTLE ENTENTE OF WOMEN(LEW), AND ITS DIFFERING REPRESENTATIONS}

The 1923 IWSA congress in Rome was arguably the key impetus for the consolidation of feminist movements in several SEE and CE countries, among other reasons because LEW was created during this congress. Women's rights and peace, as already mentioned, were two main goals of the LEW in the 1920s. In the words of Alexandrina Cantacuzino, who was a leading figure in the Romanian feminist movement of the time and the first president of the LEW, 19 'the LEW emerged from the sincere desire of our delegates in Rome to better defend the interests of women in general and to better serve the interests of our countries, on the big international feminist congresses' (1-e Conference, 1923). The ambiguous character of the LEW stems from the fact that although to a large extent compatible, the interrelationship between these two aspects - women's rights and national interests - could be differently interpreted. Starting from the fact that the nation-state was the interwar liberal feminists' main framework, but also the main object of criticism, the following analysis will discuss the differing representations of LEW. Depending on which of the two aspects would be emphasised, the LEW could be understood as a crossborder cooperation of some feminist organisations from the countries involved, or as primarily an organisation of women protecting the national interests of their countries.

Until 1929 the LEW mainly functioned through five congresses: in Bucharest (1923), in Belgrade (1924), in Athens (1925), in Prague (1927), and finally in Warsaw (1929). ${ }^{20}$ Coming from underrepresented states in Central and South-Eastern Europe, LEW members agreed that their first goal was to gain visibility and to increase participation on the international level of women's organising, specifically by having one member of the LEW in the Executive Bureau of the IWSA to represent the interests of all LEW members (Atanacković, 1923a). This was a highly successful strategy, as already at the 1923 IWSA congress, Avra Theodoropoulos from The League for Women's Rights in Greece was elected to the IWSA board. ${ }^{21}$ The visibility of women in their own countries also significantly increased due to LEW activities; in the Yugoslav case, the feminists received probably the most media coverage during the $1924 \mathrm{LEW}$ congress and its 1938 exhibition.

\footnotetext{
${ }^{19}$ She was one of the initiators of the LEW, and among many other positions held, she was the second president of the National Council of Romanian Women alongside Calypso Botez and was elected vice-president of ICW in 1925 (De Haan et al., 2006: 89-94).

${ }^{20}$ Another meeting took place in 1926 during the $10^{\text {th }}$ congress of IWSA in Paris.

21 Ana Hristić, Cantacuzino, and Plaminkova were elected as vice-presidents of the ICW board in 1925, and in 1926 Atanacković was elected a member of the IAWSEC board (Atanacković, 1923a; 1923 IWSA Report, 1923: 70; Atanacković, 1925).
}

(C) 2020 by Author/s 


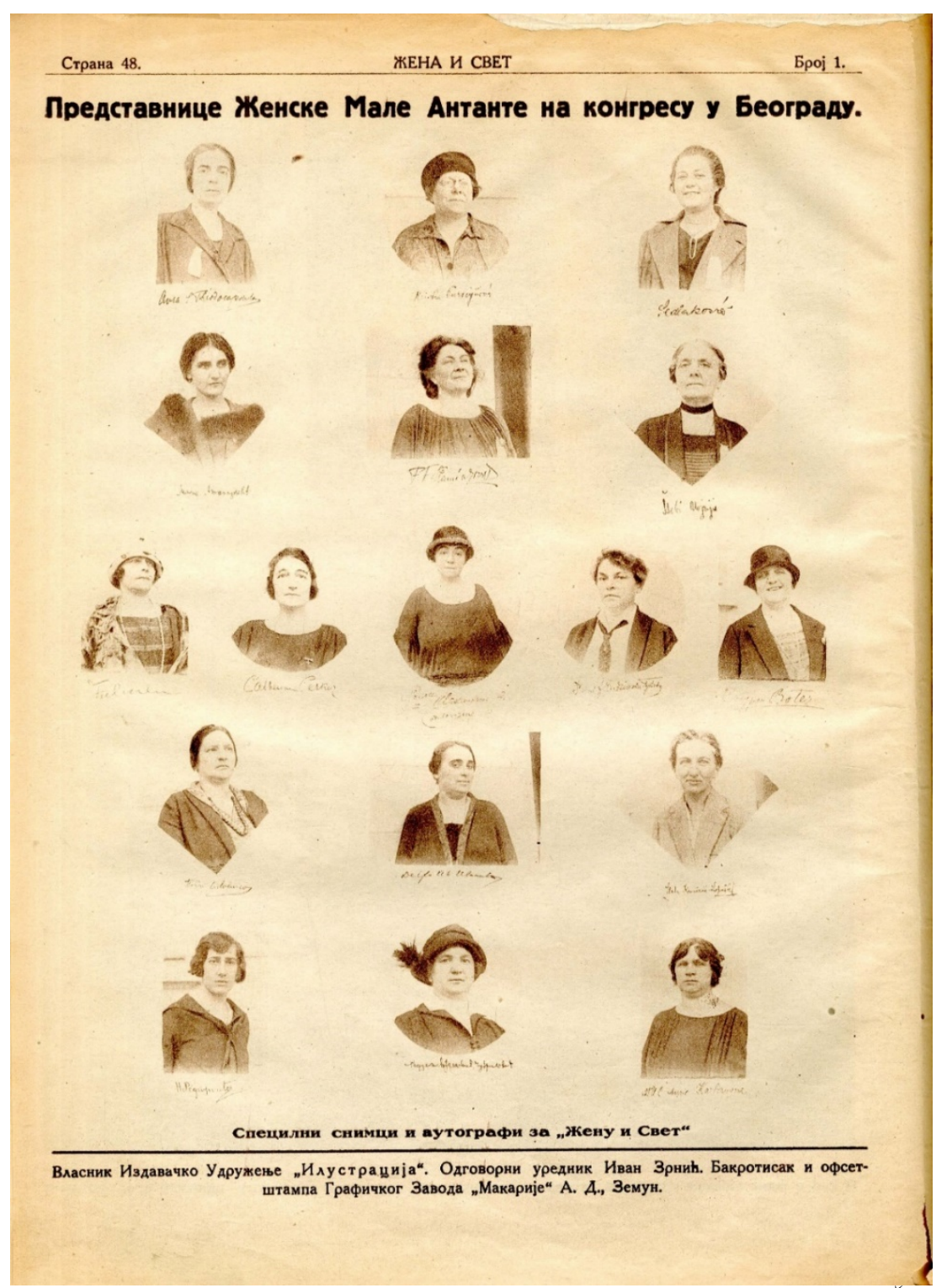

Figure 2. 'Representatives of Little Entente of Women on the congress in Belgrade.' Zena i svet, 1(1925): 48. Digitalna Narodna biblioteka Srbije, https://digitalna.nb.rs/wb/NBS/casopisi_pretrazivi_po_datumu/ zena_i_svet/1925/01/b001\#page/39/mode/1up

It can be argued that the changed type of women's cooperation in the context of the post-WWI nation-states also influenced cooperation transnationally. In the Yugoslav case, the rise of cooperation among women from Zagreb, Ljubljana, Belgrade, and other places led to the changes in representation of Kingdom SHS on the international level. Atanacković claimed that Yugoslavia was for the first time represented by a 'purely feminist delegation' (Atanacković, 1938). ${ }^{22}$ Before WWI, Ivanić and Ana Hristić ${ }^{23}$ represented Serbian women internationally, and their speeches on various international congresses were, in historian Ana Stolićs view, a 'combination of patriotic idealistic projections about the Serbian society and state, and the contemporary realistic insights' regarding the women's position. ${ }^{24}$ The Kingdom SHS's representatives at the IWSA 1920 congress in Geneva, and on the ICW 1922 executive committee meeting in Hague were also Ivanić and Hristić, and as far as it is possible to conclude by scarce reports, they still insisted more on the national than women's rights. ${ }^{25}$ Štebi

\footnotetext{
22 The delegates were: Alojzija Štebi from Ljubljana, Adela Milčinović and Milka Gutschy from Zagreb, and Katarina Bogdanović (1885-1969), Leposava Petković, Milena Atanacković from Belgrade.

${ }^{23}$ Ana Hristić (1885-1977) was a pre-war journalist and suffragist who, as a daughter of a Serbian diplomat father and Irish writer mother, travelled widely in her youth, and studied in England, where she also worked as a journalist. She worked as a nurse during the Balkan wars (1912-1913) and represented Serbia in international women's organisations before WWI. After WWI she was involved with the ICW as a representative of the Kingdom SHS.

24 (Stolić, 2018) The translation is mine (IG).

${ }^{25}$ In her report on the ICW meeting, for example, Ivanić put more emphasis on the conflict she had had with the German delegate than on women's position (Ženski pokret, 1922).
} 
opposed this kind of transnational women's activism. In her critique of Hristić's text published in the Bulletin of $I C W$ in February 1923, she argued that Hristić aimed to 'present the women's movement in Yugoslavia in the brightest colors,' and further insisted that Hristićs text was not entirely based on facts. Specifically, she claimed that the information presented to the international community concerning the cooperation of NŽS with the law drafting committees and government was nothing but a 'fantasy' (Štebi, 1923). Rather than embellishing the nationstate in front of the international audience, Štebi insisted on presenting the facts and initiated voicing more criticism towards the state from a feminist perspective.

On the LEW congresses, indeed, the women met in an international sphere and engaged in a common, crossborder criticism of their states. They addressed various feminist issues, including the questions of equal voting rights, reforms regarding the rights of children born out of wedlock, the marriage laws, the position of married women, and working mother's protection (Cheşchebec, 2005: 528-529). The official program of the LEW activities from 1923 encompassed, but was not limited to, searching for the ways in which women could attain their political, civic, and municipal rights; reaching women's legal equality with men in all LEW countries, and achieving the implementation of the already attained rights; the protection of women from various forms of exploitation; the protection of mothers and children; helping women access various professions; fighting for equal morality (Atanacković, 1938; 1-e Conference, 1923).

Importantly, in a way similar to the discussions about the FA, Atanacković consistently underlined the feminist character of the LEW in her reports in Ženski pokret. She referred to the LEW as the 'little feminist entente', and she repeated the decision of the founding meeting in Rome that 'the members [of the LEW] can be only feminist societies of these states [Yugoslavia, Romania, Bulgaria, Greece, Czechoslovakia, Poland], whereas the other societies can be represented only through them [i.e. the feminist ones]' (Atanacković, 1923a; Atanacković, 1938). ${ }^{26}$ While the feminist aspect may not have been emphasised in the official rules, it is important that the Yugoslav organisation was the self-proclaimed feminist Ženski pokret, before FA was established. What Atanacković meant by insisting the LEW was a feminist organisation was very similar to Štebi's ideas, as she clarified that the feminist movement represented 'the aspiration of women to share with men all the concerns and responsibilities for the management of the biggest social community - the state' (Atanacković, 1923b). She argued that by developing their joined work, women would make it possible that every member of society had the same rights, regardless of their sex, class or nationality (Atanacković, 1923a). Like Štebi, Atanacković defined feminism of the LEW as closely connected to the state, but the state understood as a social community.

One more clearly feminist aspect was the distinction made between male LE and the LEW, which implied a feminist type of criticism of the men's political organisation. Atanacković noted that on the Bucharest congress in 1923 'one could feel a revolt against Romanian men, who are standing on the way of their [women's] political liberation' (Atanacković, 1923b). The women stated that, while the men's Entente was based on resistance towards the enemy, the women's Entente was based on 'pacifist principles' and the idea that:

there cannot be enmity and insurmountable disagreements between two neighbouring civilized nations, and that all the difficulties in the past were created by insincere and disloyal politician's work (Ženski pokret, 1924c).

Despite the noted difficulties in practicing cross-border interwar liberal feminism as inclusive of women from the nation-states defeated in WWI, it can still be argued that along with criticising men's politics, LEW women aimed to offer a feminist conceptualisation of antirevisionist post-war politics as well.

While the reports on the LEW in Ženski pokret put more emphasis on issues such as women's rights, equality regardless of sex and class, the importance of women's participation in political life and the idea that women's public work would contribute to necessary social and legal reforms of the society, reports on the LEW in daily newspapers were less 'radical', and highlighted national aspects of the LEW. When reporting on the LEW conference held in Belgrade in 1924, for example, the daily Vreme ('Time') stressed Ivanić's and Cantacuzino's interpretations of feminism as presented through the discussion about Christianity, ('our') women in medieval times, and the harmony between men and women (Vreme, 1924a; Vreme, 1924c). And even if the previously analysed reports in Ženski pokeret underscored the cross-border feminist cooperation of the LEW members, there were other views on the LEW that rather highlighted the national character of the member states. Cantacuzino, for example, repeatedly put emphasis on the national interests of the LEW member states. On the occasion of the fourth LEW conference in Prague in 1927 she opposed the reorganisation of the LEW which would include Bulgaria, Turkey, Albania, and Hungary (Cheşchebec, 2005: 514). Taking these differing representations as a starting point, the following section will discuss them in relation to divergent ideological adherences within the interwar liberal feminist movement.

26 The Yugoslav sources, interestingly, indicate that it is only 'the feminist section' of the Romanian national women's organisation (Atanacković, 1923b). 


\section{DIVERGENT IDEOLOGIES WITHIN THE INTERWAR LIBERAL FEMINIST MOVEMENT}

The key for understanding the LEW's contested nature and its ambiguous character lies in its members' different ideological and political agendas, which would lead them to emphasise different aspects of this organisation. While all interwar liberal feminists in Yugoslavia demanded political rights for women and the right to participate in managing the state, they diverged mainly in the way they connected the social and political rights of women with the nation-state, as one group had more traditional and hierarchical views and highlighted the importance of the nation-state in ethnic terms, whereas the other group connected the question of women's rights with social justice, and the nation-state understood mainly in social terms. Debates held at the second LEW congress in Belgrade in 1924 can further illustrate the two streams in interwar liberal feminism, especially in the Yugoslav context. However, examples from the LEW congresses also suggest that this ideological divergence existed more broadly among liberal feminists gathered around the LEW.

At the 1924 LEW congress in Belgrade, the speeches of Ivanić, at that time president of NŽS SHS, and Štebi, then president of FA, highlighted the ideological divergence among interwar liberal feminists. Ivanić's welcome speech was patriotic, with references to the royal connections between Kingdom SHS and Romania, ${ }^{27}$ Christianity as the thread connecting the LEW members, and to the common 'slavery' of Greek and Serbian nations, implying the shared Ottoman past (Ivanić, 1924). She defined the centre of the LEW common work as the 'liberation of women from the century old slavery and inactivity in public work,' and the struggle for women's cultural and moral development so that they can:

freely and in an undisturbed manner put herself into the service of not only her family, as until lately, but also so that she can serve her city, her country and nation, and humanity in general (Ivanić, 1924: 393).

In defining feminism, she explained that:

God had created man and woman to live together in harmony, to prolong human race, and to care together about the happiness of their own core family, as much as for the happiness of the whole humankind (Ivanić, 1924: 395).

Whereas her speech included demands for equality of the sexes, because all individuals 'should be given same rights, without differences regarding their sex’ (Ivanić, 1924: 395), and for women's public work, it did not disregard family and nation, and did not significantly move away from her earlier claims in the tradition of pre-war national liberal feminism.

Štebi, on the other hand, insisted that the crucial question was that the LEW members decided on the main ideological principles of the organisation's feminist work (Štebi, 1924b). She restated the distinction between the humanitarian organisations of NŽS and the feminist organisations of FA and repeated that suffrage is one of the most important issues for women (Štebi, 1924c). Interestingly, a Greek delegate also highlighted that women should participate in public life through social work done on the state-level, and not through individual humanitarian organisations. According to her, humanitarian work was insufficient because 'social wounds must be solved in the roots' (Negropontes, 1924). Discussing the 'state and duties' in another speech at the Belgrade LEW conference, Śtebi proposed a reconceptualisation of the notion of politics, and for changes which would result in associating politics with morality, rather than with murder, robbery, deception, extortion, viciousness, lies, and corruption. She invited morality back into the liberal institutions which she, as a liberal feminist, considered important. The way to improve these institutions was, ultimately, through the state. However, she was aware that her approach to the nation-state was uncommon, and added with a bit of irony:

You may have been disappointed with my performance about the questions of state and the duties and rights of citizens, as I do not refer to the state as a formation surrounded by the halo of holiness and inviolability, and as I do not list the duties and rights of citizens according to the points we had been taught by the school books taken from the millennial tradition. I also did not offer the recipe that would list how many grams of patriotism, how many grams of loyalty should be poured on each person in order to arouse their citizenship consciousness. I have not given it to you and I cannot give it to you (Stebi, 1924a).

${ }^{27}$ Queen Maria Karađorđević of Kingdom SHS was the daughter of the Romanian King and Queen. 
What she did offer, however, was the notion that the essence of every human being was in the 'unwavering sense of solidarity with one's neighbour' and:

in the courage to know the truth and to profess it in all life's examples and in commitment against all immorality in private and public life (Štebi, 1924a).

This, Štebi argued, was the essence of the feminist movement. Her speeches imply a conscious effort to move away from the patriotic discourses that demonstrated a 'millennial tradition', such as Ivanić's speech referring to Serbian women in medieval times. Instead, Štebi offered a specific understanding of citizenship based on the equality and solidarity of all citizens. As in the case of the LEW reports analysed in the previous section, Štebi's speeches once more indicate that, for one group of interwar liberal feminists, feminism was inseparable from the demands for social justice. Finally, she voiced dissent towards the male political establishment, arguing for changes in politics and in citizenship that would not only include women, but bring a more just system for all. ${ }^{28}$

The discussion about the reform of the law regarding children born out of wedlock is a good example that suggests a transnational divergence among interwar liberal feminists. The participants at the Belgrade LEW congress debated the leading principles for their countries Civil Codes' reform regarding women and children, specifically the law which prohibited the search for the father of children born outside marriage. The liberal feminists saw this law as the cause of a profound inequality between women and men, as well as inequality between children born within and out of wedlock. After the presentations of the laws in all the LEW member countries, the representatives agreed unanimously on the necessity to change the laws, so that children born out of wedlock would have the same legal rights as those born in marriage (Ženski pokret, 1924a; Cantacuzino, 1924). Because the number of orphans and children born out of wedlock was high, Czech representative Plamínková suggested that the congress adopt a resolution that demands a system of a common fund under the state's control, into which fathers of all children born out of wedlock would pay (Vreme, 1924b). While this suggestion was accepted by all, there were two conflicting suggestions of how to operate this fund. One group, including Ivanić, the Romanian representatives Cantacuzino and Calypso Botez (Bucur, 2001), and Czech representative and member of the Czech parliament Eliška Purkyňová, supported a proposal that the fathers contribute to the fund proportionally according to their income, and that the children receive income proportionally to their father's payments. The other group, which included the Polish representatives, and Plaminkova, Štebi, Atanacković, and Theodoropoulou, ${ }^{29}$ voted for the proposal that the fathers contribute proportionally, but that all the children receive an equal income. This proposal was described in the press as the 'more progressive one as it will abolish the difference between the illegitimate child of a prince and that of a worker' (Vreme, 1924b). Ivanić argued that the second option would not be fair, as it would deprive the children of their rights, whereas the other group argued, according to the laws of social justice, that all children have equal rights to live (Ženski pokret, 1924a). No agreement was reached and both resolutions were adopted at this session of the LEW. The plan was to use these resolutions through the League of Nations and the member country's parliaments in order to make changes in the legal system (Vreme, 1924b).

These examples demonstrate that in the early 1920s in the Yugoslav movement, and possibly also within the LEW, interwar liberal feminists cooperated on several issues concerning reforms of the legal and political system of their states, with the aim of making changes that would significantly improve the position of women and children. However, while they agreed on the question of the inequality of the sexes and their trust in the liberal state, they had different understandings of the national state, and of class inequality. In addition, the meaning of the concept of feminism, although inseparable from demands for women's political rights, was contested as well, as one group connected it with issues of social justice, while the other group - with notions such as family harmony.

\section{CONCLUSIONS}

The aim of this article was to enhance our current understanding of interwar feminisms by examining the interconnected histories of the emergence and growth of the Yugoslav state-wide feminist network FA and the regional feminist organisation LEW in the early 1920s. I suggested that LEW and FA should be understood within the context of the consolidation of the post-WWI feminist movement in 1923, with all precautions of taking one year as crucial for such kind of change. The term interwar liberal feminism was proposed for a better understanding of these two organisations, as well as more generally for interwar feminisms in some countries of CE and SEE Europe. Interwar liberal feminism emerged as a result of a changed type of cooperation among women after WWI,

\footnotetext{
${ }^{28}$ This speech is in many ways comparable to Polish representative Justyna Budzińska-Tylicka's speech on the first LEW congress in Bucharest (1-e Conference, 1923: 14-19). As Štebi, Budzińska-Tylicka (1867-1936) was close to the socialist ideas (De Haan et al., 2006: 80-84).

${ }^{29}$ Theodoropoulou was a musicologist and the leading figure in the Greek feminist movement, founder and president of the League for Women's Rights, and after 1923 - board member of the IWSA/IAWSEC (De Haan et al., 2006: 569-574).
}

(C) 2020 by Author/s 
in the context of the establishment of new nation-states. In the Kingdom of SHS/Yugoslavia, following initial enthusiasm regarding the establishment of the new state, there was disillusionment because women were not recognised equal social and political rights. Consequently, women began to cooperate more closely with each other, challenging the state from a feminist perspective. Such increased cooperation also developed in some of the countries where women were granted political rights, for example in Czechoslovakia.

For the interwar liberal feminists, the nation-state was the main framework of reference, but it was also the main object of criticism. This type of feminism was defined in the article as the feminists' adherence to the liberal constitutional systems of their post-WWI nation-states, and a belief in the possibility of reforming the new states through parliamentary means. The reforms demanded by liberal feminists were primarily those connected to women's unequal position as citizens of the new states. However, the pluralist character of interwar liberal feminist organisations allowed for ideological differences within the movement, which was the case within the Yugoslav feminist movement. While the interwar liberal feminists agreed that reforms to improve women's position were needed, they differed in the way they connected the social and political rights of women with the nation-state. One group, illustrated in this article by Delfa Ivanićs argumentation, put more emphasis on women's contribution to the ethnic-nation and family, conceptualised feminism as an attainment of harmony between women and men, and posited a more traditional and hierarchical understanding of society. The other group, exemplified here by Alojzija Śtebi and Milena Atanacković, connected the concept of feminism and the question of women's political rights with social justice and equality of all citizens, regardless of their sex, ethnicity, or class. The latter also insisted on women's contribution to the nation-state through public and social work, rather than through traditional humanitarian work.

The sources furthermore point to a strong possibility that this ideological divergence existed more broadly within the interwar liberal feminist movement in SEE and CE, which helps explain LEW's ambiguous character. Namely, because of the twofold definition of the LEW's goals, which was both women's rights and peace, and because of the fact that the post-WWI nation-state was simultaneously the main framework and the main object of critique for the interwar liberal feminists, there were differing representations of the LEW. LEW could be understood as principally a cross-border organisation of women who joined on a transnational level to demand reforms on the national levels. Yet, the antirevisionist position of the LEW made it difficult for the LEW to become an organisation which would enable the cross-border cooperation of feminists from all SEE and CE countries, including those defeated in WWI. It is because of this that LEW could also be presented as an antirevisionist organisation of national women's groups. LEW was ambiguous, i.e. difficult to classify, because differing representations of the organisation would be produced depending on which of the two aspects of the organisation would be highlighted. In order to explain the LEW's contested nature and its ambiguous character, then, it is useful to explore its members' divergent views on society and the nation-state as discussed above, which would lead them to emphasise different aspects of this organisation.

For further research of the history of this interwar regional alliance, I propose as a useful interpretive perspective to explore a) the entanglements of the LEW and its national member organisations, and b) ideological divergences within each national section, to be explored, in turn, in their transnational impact. Although my analysis here was limited to the Yugoslav sources, it suggests that this approach to researching the LEW could be more effective than examining it as a multiplication of five homogeneous national sections.

\section{ACKNOWLEDGEMENTS}

This article is partly based on my doctoral research on the history of feminisms in interwar Yugoslavia from a transnational perspective, at the Department of History at the Central European University in Budapest. I would like to thank all who helped me in different stages of writing this article: my supervisors Balázs Trencsényi and Francisca de Haan, the journal issue editors and two anonymous reviewers, as well as my colleagues Zsófia Lóránd, Elvira Ibragimova, Ivana Mihaela Žimbrek, Francesca Rolandi, Vojtěch Pojar, Stefan Gužvica, and Lovro Kralj for their perceptive comments and questions on different versions of this text.

\section{REFERENCES}

1923 IWSA Report of Ninth Congress, Rome, Italy, May 12th to 19th (1923). Available at: Women and Social Movements, International Database: https://alexanderstreet.com/products/women-and-social-movementsinternational-1840-present (Accessed 20 September, 2019).

1-e Conference de la Petite Entente des Femmes. Discourses Prononces aux seances publiques des 3 et 4 Novembre 1923. (1923). Bucurest: Tipografia « Dorneanu » Calea Mosilor. Folder 51/1923, Fond 1224 - Fond Familial Cantacuzino, National Central Historical Archives Bucharest, Romania. 
Adám, M. (1993). The Little Entente and Europe, 1920-1929. (M. Esterházy, and N. Thurston, Trans.) Budapest: Akadémiai Kiadó.

Albrechtova, V. (1924). Za mir in svobodo. Ženski pokret (1/2), 12-18.

Atanacković, M. (1923a). Mala feministička antanta, liga za mir i slobodu. Ženski pokret (6), 264-268.

Atanacković, M. (1923b). Mala ženska antanta. Ženski pokret (9/10), 420-429.

Atanacković, M. (1925). Izveštaj sa kongresa ICW u Vašingtonu. Ženski pokret (9/10), 325-331.

Atanacković, M. (1927). IV Konferencija Male ženske antante. Ženski pokret (10), 1-2.

Atanacković, M. (1938). Mala ženska antanta. Glasnik Jugoslovenskog ženskog saveza, 4(1/2), 1-2.

Barać, S. (2015). Feministickea kontrajavnost. Žanr ženskog portreta u srpskoj periodici 1920-1941. Beograd: Institut za književnost i umetnost.

Bogdanović, K. (1921). Na početku druge godine. Ženski pokret (1), 1-5.

Bucur, M. (2001). Calypso Botez: A feminist critique of interwar Romanian politics. Jabrbucher fur Geschichte und Kultur Suedosteuropas 3, 63-78.

Bucur, M. (2007). Between liberal and republican citizenship. Feminism and nationalism in Romania, 1880-1918. Aspasia, 1(1), 84-102.

Cantacuzino, A. (1924). Pozdravni govor g-đe Kantakuzen, predsednice M.Ž.A. Ženski pokret (9), 340.

Cheşchebec, R. (2005). Feminist Ideologies and Activism in Romania (approx 1890-1940s). Nationalism and internationalism in Romanian projects for women's emancipation. Budapest: $\mathrm{PhD}$ diss., Central European University.

Crampton, R. (2007). The Balkans, in R. Gerwarth (ed), Twisted Paths: Europe 1914-1945 (pp. 237-270). Oxford: Oxford University Press.

Daskalova, K. (2006). Bulgarian Women's Movement (1850-1940), in E. Saurer, M. Lanzinger, and a. E. Frysak (eds), Women's Movements: Networks and Debates in Post-Communist Countries in the 19th and 20th Centuries (pp. 413438). Köln: Böhlau.

Daskalova, K. (2008). Balkans, in B. G. Smith (ed), Women in World History (pp. 185-195). Oxford: Oxford University Press.

Daskalova, K. (2018). Little Entente of Women/Malkata zhenska antanta i feministkite dvizhenia na Balkanite prez 20-te i 30-te godini na XX vek. Sotsiologicheski problemi, 50(2), 675-695.

Daskalova, K., and Zimmermann, S. (2017). Women's and gender history, in L. A. Klimo (ed), The Routledge History of East Central Europe Since 1700 (pp. 278-322). New York: Routledge.

De Haan, F. (2017). Writing inter/transnational history: The case of women's movements and feminisms, in B. Haider-Wilson, W. D. Godsey, and W. Mueller (eds), Internationale Geschicbte / International History (pp. 501-536). Wien: Verlag der österreichischen Akademie.

De Haan, F., Daskalova, K., and Loutfi, A. (2006). A Biographical Dictionary of Women's Movements and Feminisms. Central, Eastern, and South Eastern Europe: 19th and 20th centuries. Budapest, New York: Central European University Press.

Delap, L. (2009 [2007]). The Feminist Avant-Garde. Transatlantic encounters of the early twentieth century. New York: Cambridge University Press.

Dojčinović, B., and Kolarić, A. Feministički časopisi u Srbüi: Teorïa, aktivizam i umetničke prakse u 1990-tim i 2000-tim. Filološki fakultet Univerziteta u Beogradu: Beograd, 2018). https://doi.org/10.18485/femjis.2018 (Accessed 15 April, 2020).

Emmert, T. A. (1999). Ženski pokret: The Feminist Movement in Serbia in the 1920s, in S. P. Ramet (ed), Gender Politics in the Western Balkans: Women and society in Yugoslavia and the Yugoslav successor states (pp. 33-49). University Park, PA: Pennsylvania State University Press.

Evans, R. J. (2007). The Successor States, in R. Gerwarth (ed), Twisted Paths: Europe 1914-1945 (pp. 210-236). Oxford: Oxford University Press.

Feinberg, M. (2006). Elusive Equality: Gender, citizenship and the limits of democracy in Czechoslovakia, 1918-1950. Pittsburgh, PA: University of Pittsburgh Press.

Gleadle, K., and Thomas, Z. (2017). Global feminisms, c. 1870-1930: Vocabularies and concepts—a comparative approach. Women's History Review, 27(7), 1-16.

Horne, R. G. (2012). War in Peace: Paramilitary violence in Europe after the Great War. Oxford: Oxford University Press. Ivanić, D. (1924). Svečana sednica male ženske antante, Pozdrav. Ženski pokret (10), pp. 392-396.

Janine-Calic, M. (2019 [2014]). A History of Yugoslavia. (D. Geyer, Trans.) West Lafayette: Indiana: Purdue University.

Janković, Z. V. (1921). Dvadesetgodišnjica Splošnog Ženskog Društva u Ljubljani. Ženski pokret (7/8), 255-258.

Janz, O., and Schönpflug, D. (2014). Gender History in a Transnational Perspective: Biographies, networks, gender orders. New York, Oxford: Berghahn.

Karadžić, Z. K. (1921). Izveštaj UO Društva za prosvećivanje žene i zaštitu njenih prava. Ženski pokret (4), 117 124. 
Karadžić, Z. K. (1922). Ženski pokret kod nas i na strani. Ženski pokret (1/2), 19-27.

Kecman, J. (1978). Žene Jugoslavije u radnickeom pokretu $i$ ženskim organizacijama 1918-1941. Beograd: Narodna knjiga: Institut za savremenu istoriju.

Kolarić, A. (2019). Gender identities in women's and feminist periodicals in Serbia. Aspasia, 13(13), 175-181.

Kolarić, A. (2016). Rod, modernost i emancipacija. Uredničke politike u časopisima "Žena" (1911-1914) $i$ "The Freewoman" (1911-1912). Beograd: Fabrika knjiga.

Lebl Albala, P. (2005). Tako je nekad bilo. Beograd: Aleksandar Lebl.

MacMillan, M. (2002). Paris 1919: Six months that changed the world. New York: Random House.

Milanović, J. (2015). Delfa Ivanić. Zaboravljene uspomene. Beograd: Evoluta.

Milanović, J. (2017). Regionalna ženska udruženja, Mala Antanta žena i Jedinstvo slovenskih žena, in Jugoslavija $i$ Poljska u XX veku: medunarodni tematski z̧bornik radova sa konferencije Jugoslovensko-poljski odnosi u XX veku. Beograd, Bidgošć: Institut za savremenu istoriju : Društvo istoričara Srbije "Stojan Novaković", Institut za istoriju i međunarodne odnose.

Milinković, J., and Svirčev, Ž. (2019). Ženski pokret (1920-1938). Politika teksta i konteksta, in J. Poljak and O. Ivanova (eds), Ženski pokret (1920-1938): Bibliografija (pp. 7-30). Beograd: Institut za književnost i umetnost. https://www.zenskipokret.org/wp-content/uploads/2020/01/J.Milinkovi\%C4\%87-\%C5\%BD.-

Svir\%C4\%8Dev-Politika-teksta-i-konteksta.pdf (Accessed April 15, 2020).

Negropontes, H. (1924). Feminizam u Grčkoj. Ženski pokret (9), 348-351.

Newman, J. P. (2017). Revolution and counterrevolution in Europe 1917-1923, in S. P. Smith (ed), The Cambridge History of Communism (pp. 74-95). Cambridge: Cambridge University Press.

Ograjšek Gorenjak, I. (2014). Opasne ilurije. Rodni stereotipi u međuratnoj Jugoslaviji. Zagreb: Srednja Europa.

Ograjšek Gorenjak, I., and Kardum, M. (2019). Mala ženska antanta (1923-1929): mali savez s velikim ambicijama. Historijski zbornik, 72(1), 111-138.

Peković, S. (2015). Časopisi po meri dostojanstvenog ženskinja. Ženski časopisi na početku 20. veka. Novi Sad, Beograd: Matica Srpska, Institut za književnost i umetnost.

Petranović, B. (1988). Istorija Jugoslavije 1918-1988 (Vol. 1). Beograd: Nolit.

Rupp, L. (1997). Worlds of Women: The making of an international women's movement. Princeton, New Jersey: Princeton University Press.

Selišnik, I. (2011). Alojzija Štebi, socialna feministka in ena prvih političark v Sloveniji. In M. A. Gaber, Ženskee na robivih politike (pp. 41-59). Ljubljana: Založba Sophia.

Štebi, A. (1922a). O problemu prostitucije. Ženski pokeret (1/2), 11-18.

Štebi, A. (1922b). O zaščiti dece in mladine. Ženski pokret (3/4), 79-86.

Štebi, A. (1923). Netačni izveštaji. Ženski pokret (8), 265-267.

Štebi, A. (1924a). Država in dolžnosti. Ženski pokret (9), 381-387.

Štebi, A. (1924b). Feminističko pitanje. Ženski pokret (9), 376.

Štebi, A. (1924c). Mišljenje javnosti i feminizam u Jugoslaviji. Ženski pokret (9), 376-378.

Štebi, A. (1924d). Za novi smer u feminističkom pokretu. Ženski pokret (7), 241-251.

Stefanović, S. (2013). Nation und Geschlecht. Frauen in Serbien von der Mitte des 19. Jabrbunderts bis zum Zweiten Weltkrieg. Leipzig: PhD diss., Universität Leipzig. https://nbn-resolving.org/urn:nbn:de:bsz:15-qucosa-203559 (Accessed February 1, 2019).

Stefanović, S. (2000) Žensko pitanje u beogradskoj štampi i periodici. Belgrade: Mr. diss., University of Belgrade (unpublished).

Stibbe, I. S. (2017). Women Activists Between War and Peace. Europe, 1918-1923. London, New York: Bloomsbury.

Stolić, A. (2015). Sestre srpkinje. Beograd: Evoluta.

Stolić, A. (2018). Ižmeđu nacionalizma i internacionalizma. Sppkinje na kongresima organizacija Medunarodnog ženskog pokreta do Prvog svetskog rata. Available at: Istorijski institut, Portal za žensku i rodnu istoriju: https://zristorija.iib.ac.rs/istrazivanja/izmedju-nacionalizma-i-internacionalizma-srpkinje-na-kongresimaorganizacija-medjunarodnog-zenskog-pokreta-do-prvog-svetskog-rata/. (Acessed 1 September, 2019).

Svirčev, Ž. (2015). Jugoslavenska žena - forum moderne spisateljice. Knjiž̌enstvo, 5(5). https://doi.org/10.18485/knjiz.2015.1.22 (Accessed May 20, 2020).

Vreme. (1924a). Danas se otvara kongres Ženske Male Antante. V reme, 30 October, p. 5.

Vreme. (1924b). Sednica posvećena detetu, ljubavniku i mužu. Vreme, 01 November, p. 3.

Vreme. (1924c). Žene male antante počinju svoje delo. Vreme, 29 October, p. 5.

Werner, M., and Zimmermann, B. (2006). Beyond comparison: Histoire croisée and the challenge of reflexivity. History and Theory, 45, 30-50.

Z.K. (1920). Godišnja skupština Društva za prosvećivanje žene i zaštitu njenih prava. Ženski pokret (2), 14-16.

Ženski pokret. (1921a). Rad Društva za prosvećivanje žene i zaštitu njenih prava (od maja do novembra). Ženski pokret (9/10), 325-328. 
Ženski pokret. (1921b). Velika skupština za žensko pravo glasa. Ženski pokret (4), 124-127.

Ženski pokret. (1922). Izveštaj našeg delegata sa sednice. Ženski pokret (7/8), 218.

Ženski pokret. (1923a). Alijansija feminističkih društava. Ženski pokret (7), 326.

Ženski pokret. (1923b). Pravila feminističke aliancije u državi SHS. Ženski pokret (9/10), 455-460.

Ženski pokret. (1924a). Diskusija o vanbračnom detetu. Ženski pokret (9), 374-375.

Ženski pokret. (1924b). Izveštaj g-đice Čerkez, sekretara M.Ž.A. Ženski pokret (9), 341-342.

Ženski pokret. (1924c). Izveštaj UO ženskog pokreta za godišnju skupštinu. Ženski pokeret (7), 292.

Ženski pokret. (1929). Konferencija Male Ženske Antante održana u Varšavi 25-28 juna. Ženski pokret (13-16), 2.

Citation: Grubački, I. (2020). The Emergence of the Yugoslav Interwar Liberal Feminist Movement and the Little Entente of Women: An Entangled History Approach (1919-1924). Feminist Encounters: A Journal of Critical Studies in Culture and Politics, 4(2), 27. https://doi.org/10.20897/femenc/8515

Copyright (C) 2020 by Author/s and Licensed by Lectito BV, Netherlands. This is an open access article distributed under the Creative Commons Attribution License which permits unrestricted use, distribution, and reproduction in any medium, provided the original work is properly cited. 